\title{
Karakteristik Unjuk Kerja Mesin Diesel Menggunakan Bahan Bakar B100 dan B20 Dalam Jangka Panjang
}

\author{
W. Saputro*, J. Sentanuhady, A.I. Majid, W. Prasidha, N.P. Gunawan, T.Y. Raditya \\ Departemen Teknik Mesin dan Industri, Fakultas Teknik, Universitas Gadjah Mada. \\ Jl. Grafika No.2, Kompleks UGM, Yogyakarta 55281, Indonesia, \\ Telp. (0274) 521673 \\ *e-mail: wiliandisaputro@mail.ugm.ac.id
}

\begin{abstract}
Abstrak
Penggunaan bahan bakar alternatif selalu berkaitan dengan dua masalah global, yaitu meningkatnya penggunaan minyak mentah dan cadangan minyak yang semakin menurun. Disamping itu, sumber energi alternatif menjadi topik yang menarik untuk terus dikaji. Indonesia adalah salah satu negara penghasil minyak kelapa sawit terbesar di dunia dengan nilai produksi mencapai 51,8 juta ton pada tahun 2019. Salah satu sumber energi alternatif yang dapat diolah dari minyak sawit adalah biodiesel. Biodiesel dapat digunakan secara langsung sebagai bahan bakar untuk mesin diesel. Tetapi biodiesel memiliki karakteristik yang berbeda dengan solar sehingga akan mempengaruhi unjuk kerja dan hal lainnya pada mesin. Oleh karena itu, penelitian ini akan menentukan pengaruh penggunaan biodiesel terhadap unjuk kerja mesin yang mencakup daya mesin, torsi, konsumsi bahan bakar spesifik (SFC), dan efisiensi termal. Bahan bakar yang digunakan adalah B100 (100\% biodiesel minyak sawit) dan bahan bakar B20 (20\% biodiesel minyak sawit $+80 \%$ solar) sebagai pembandingnya. Pengujian dilakukan selama 300 jam operasi, dengan beban konstan berupa lampu halogen sebesar $4 \mathrm{~kW}$. Menurut hasil penelitian, mesin berbahan bakar B100 menghasilkan daya, torsi, dan efisiensi termal yang lebih rendah masing-masing sebesar 2,17\%; 0,76\%; dan 1,25\% serta menghasilkan SFC yang lebih tinggi sebesar $14,61 \%$ bila dibandingkan dengan mesin berbahan bakar B20. Hal tersebut dikarenakan karakteristik bahan bakar B100 yang memiliki nilai kalor lebih rendah dan viskositas serta densitas lebih tinggi dibandingkan bahan bakar B20.
\end{abstract}

Kata kunci : Biodiesel, mesin diesel, minyak sawit, unjuk kerja, jangka panjang.

\begin{abstract}
The implementation of alternative fuels is always related to two global problems, which are, the increasing use of crude oil and the decreasing of oil reserves. Moreover, the source of alternative energy has become an interesting topic to be discussed. Indonesia is one of the countries that have the largest production of palm oil in the world with a production value of 51.8 million tons in 2019. One of the alternative energy sources that can be processed from palm oil is biodiesel. Biodiesel can be directly used as fuel of Diesel Engines. However, biodiesel has different characteristics with diesel fuel, so it will affect the performance and other things of the engine. Therefore, this study will determine the impact of the use of biodiesel towards the performance of the engine, which includes the power of the engine, torque, specific fuel consumption (SFC), and the thermal efficiency. The fuels used are B100 (100\% biodiesel of palm oil) and B20 (20\% biodiesel of palm oil and $80 \%$ of diesel fuel) as the comparison. The test was carried out for 300
\end{abstract}


hours of operation, with a constant load of $4 \mathrm{~kW}$ halogen lamps. According to the results of the study, the engine with B100 as the fuel has lower power, torque, and thermal efficiency by $2.17 \% ; 0.76 \%$; and $1.25 \%$ respectively, and produces a higher SFC of $14.61 \%$ when compared to the B20 fueled engine. This is due to the characteristics of B100 fuel which has a lower heating value and higher viscosity and density than B20 fuel.

Keywords : Biodiesel, diesel engine, palm oil, performance, long term.

\section{PENDAHULUAN}

Saat ini penggunaan bahan bakar alternatif terutama pada mesin pembakaran dalam telah menjadi objek yang menarik untuk terus dikembangkan. Penggunaan bahan bakar alternatif tidak bisa lepas dari dua masalah global yaitu ketersediaan minyak mentah yang terus menurun dan masalah emisi gas buang yang semakin memprihatinkan. Minat masyarakat yang cukup tinggi terhadap bahan bakar solar ditunjukkan dengan terjadinya kenaikan konsumsi bahan bakar solar. Kenaikan tersebut menunjukkan bahwa jenis bahan bakar minyak solar pada tahun 2017 mengalami peningkatan sebesar 764,5 juta kilo liter. Kenaikan konsumsi bahan bakar solar merupakan permasalahan yang harus diantisipasi, karena solar merupakan bahan bakar minyak yang diolah dari crude oil yaitu bahan bakar yang terbuat dari fosil sehingga bukan merupakan bahan bakar yang dapat diperbarui. Jika konsumsi bahan bakar solar tidak dikendalikan, maka keberadaan crude oil akan semakin berkurang dan akan habis pada tahun 2053.

Salah satu produk dari diversifikasi bahan bakar yang dapat digunakan sebagai pengganti bahan bakar solar adalah biodiesel. Biodiesel merupakan bahan bakar yang dapat dihasilkan dari proses transesterifikasi. Biodiesel dapat dihasilkan dengan memanfaatkan minyak nabati, lemak hewan, minyak goreng bekas, dan alga sehingga biodiesel dapat dikatakan sebagai bahan bakar yang dapat diperbarui, mudah terurai, tidak beracun, dan ramah lingkungan. Salah satu tanaman penghasil biodiesel yang sangat potensial untuk dikembangkan di Indonesia adalah kelapa sawit.

Penelitian terkait efek pemakaian bahan bakar B100 dari Crude Palm Oil (CPO) telah dilakukan dengan total waktu pengujian selama 800 jam operasi. Pengujian dilakukan selama 12 jam per hari untuk menggerakkan paddlewheel aerator di kolam ikan. Mesin yang digunakan adalah mesin diesel Kubota RT140 direct injection dengan daya 14 horse power. Putaran mesin konstan pada $1000 \mathrm{rpm}$. Hasil penelitian tersebut menunjukkan bahwa konsumsi bahan bakar rata-rata pada bahan bakar B100 lebih tinggi 10,6\% dibandingkan bahan bakar diesel. Hal ini terjadi dikarenakan nilai kalor spesifik bahan bakar B100 lebih rendah 11\% dibanding bahan bakar diesel. Untuk efisiensi termal yang dihasilkan dari penggunaan bahan bakar B100 memiliki nilai yang hampir sebanding dengan bahan bakar diesel, yaitu 15,1\% dan 15,3\% secara berurutan.

Alloune et al., meneliti terkait karakteristik performa mesin diesel dengan bahan bakar biodiesel yang terbuat dari Citrullus colocynthis L (CCME). Campuran bahan bakar biodiesel yang digunakan adalah B30 dan B100, serta bahan bakar diesel digunakan sebagai pembandingnya. Putaran mesin konstan pada $1500 \mathrm{rpm}$ dengan pembebanan bervariasi. Mesin dihubungkan dengan dynamometer elektrik sebagai pembebanan. Berdasarkan hasil pengujian, diketahui bahwa pada pembebanan mesin rendah sampai medium yaitu 1,1-3,5 kW, brake thermal efficiency (BTE) pada bahan bakar B100 lebih tinggi 4,5\% dibandingkan bahan bakar B30 dan lebih tinggi 9,6\% dibandingkan bahan bakar diesel. Hal ini dapat terjadi dikarenakan kandungan oksigen pada bahan bakar B100 lebih tinggi dibandingkan bahan bakar B30 sehingga meningkatkan 
proses pembakaran. Saat pembebanan penuh, BTE pada bahan bakar B100 lebih rendah dibanding bahan bakar B30 tetapi sedikit lebih tinggi dibanding bahan bakar diesel. Brake specific fuel consumption (BSFC) pada bahan bakar B100 lebih tinggi dibanding bahan bakar B30 dan bahan bakar diesel untuk seluruh variasi pembebanan. Hal ini terjadi dikarenakan bahan bakar B100 memiliki nilai kalor yang lebih rendah sehingga menyebabkan konsumsi bahan bakar meningkat untuk menjaga energi input pada mesin. Berdasarkan penelitiannya juga diketahui penggunaan bahan bakar B100 meningkatkan efisiensi sebesar 5\% dibandingkan dengan bahan bakar diesel, namun bahan bakar B100 memiliki nilai kalor 12\% lebih rendah dibandingkan bahan bakar diesel. Sedangkan bahan bakar B30 memiliki nilai kalor 4\% lebih rendah dari bahan bakar diesel, tetapi efisiensinya dapat meningkat sebesar 1-6\% dibandingkan bahan bakar diesel dan mengakibatkan BSFC bahan bakar B30 lebih rendah dibandingkan bahan bakar diesel pada pembebanan tinggi. Ozsezen et al., juga melakukan penelitian terkait dengan karakteristik performa mesin diesel yaitu menggunakan bahan bakar waste palm oil methyl ester (WPOME) dan canola oil methyl ester (COME). Parameter yang diteliti diantaranya brake torque maksimum, brake power (BP), brake specific fuel consumption (BSFC), dan brake thermal efficiency (BTE). Kondisi pengujian mesin dilakukan dengan pembebanan penuh pada putaran mesin sebesar $1500 \mathrm{rpm}$. Bahan bakar diesel petroleum (PBDF) digunakan untuk pembanding dalam penelitian ini. Berdasarkan hasil pengujian diketahui bahwa brake torque maksimum pada WPOME dan COME adalah 320,24 Nm dan 319,8 Nm, di mana nilai tersebut lebih rendah dibanding PBDF dengan brake torque maksimum sebesar 328,7 Nm. Untuk nilai BSFC pada WPOME diketahui lebih tinggi 7,48\% dari PBDF, sedangkan untuk nilai BSFC pada COME diketahui lebih tinggi 6,18\% dari PBDF. Nilai BP pada WPOME dan COME adalah 50,78 kW dan 50,71 kW, nilai tersebut lebih rendah dibanding dengan PBDF dengan BP sebesar 52,12 kW. Nilai BTE pada WPOME lebih rendah 1,42\% dibandingkan PBDF, sedangkan nilai BTE pada COME lebih rendah 0,12\% dibandingkan PBDF.

Meskipun secara teoritis bahan bakar biodiesel dapat digunakan langsung sebagai bahan bakar untuk mesin diesel. Namun penelitian terkait penggunaan bahan bakar biodiesel dari Crude Palm Oil (CPO) terhadap unjuk kerja mesin dalam jangka panjang masih sangat sedikit, sehingga berpotensi untuk dikembangkan lebih jauh. Hal ini dikarenakan di setiap daerah atau negara memiliki nilai karakteristik CPO yang berbeda-beda. Berdasarkan perbedaan karakteristik CPO dan kondisi pengujian yang sudah dilakukan, oleh karena itu pada penelitian ini dilakukan pengujian mesin nonstop dengan total waktu 300 jam operasi. Pembebanan menggunakan lampu halogen sebesar $4 \mathrm{~kW}$, serta kecepatan mesin konstan pada $2200 \mathrm{rpm}$. Tujuan dari penelitian ini adalah menentukan efek pemakaian bahan bakar B100 dan B20 terhadap unjuk kerja mesin diesel yaitu daya poros mesin, torsi, specific fuel consumption (SFC), dan efisiensi termal pada jangka panjang.

\section{METODE PENELITIAN}

\subsection{Experimental Set-Up}

Penelitian ini menggunakan dua unit mesin yang bertipe sama yaitu mesin diesel Kubota seri RD 65 DI NB dengan kapasitas volume silinder 376 cc dan juga menggunakan pelumas yang sama yaitu Pertamina Meditran SX Bio SAE 15W-40. Masing-masing mesin dihubungkan dengan generator listrik berkapasitas $5 \mathrm{~kW}$ dengan efisiensi diasumsikan sekitar 80\% yang digunakan untuk menyalakan empat lampu halogen yang masing-masing memiliki daya sebesar $1 \mathrm{~kW}$ kemudian dirangkaikan paralel, sehingga daya totalnya sebesar $4 \mathrm{~kW}$ yang berfungsi sebagai pembebanan mesin. Daya poros diukur dengan membagi total daya output pembebanan 
dengan efisiensi generator. Kedua mesin diatas menggunakan dua bahan bakar yang berbeda, yaitu bahan bakar B100 dan B20, yang semuanya diuji selama 300 jam operasi dengan kecepatan konstan $2200 \mathrm{rpm}$. Gambar skematis alat pengujian dapat dilihat pada Gambar 1.

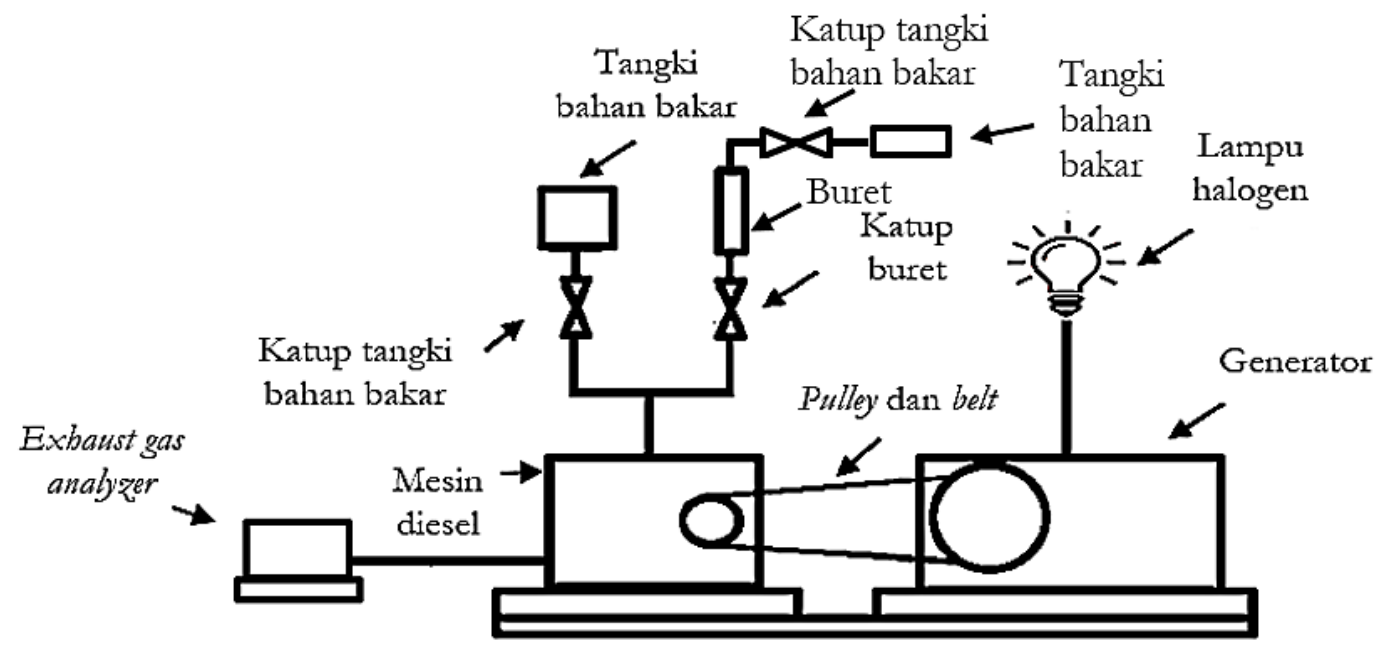

Gambar 1. Skematis alat pengujian.

Kemudian peralatan ini dihubungkan dengan peralatan pendukung seperti buret untuk mengukur konsumsi bahan bakar per satuan waktu, sensor rpm, peralatan untuk mengukur arus dan tegangan, serta digital infrared termogun untuk mengukur suhu komponen mesin. Selanjutnya guna mengukur emisi bahan bakar digunakan exhaust gas analyzer dengan merek Tecnotest, model Stargas 898. Pengukuran konsumsi bahan bakar menggunakan teknik manual dengan buret yang memiliki kapasitas $20 \mathrm{ml}$, kemudian diukur waktu mesin menghabiskan bahan bakar $20 \mathrm{ml}$ tersebut dengan menggunakan stopwatch. Suhu cylinder block diukur menggunakan digital infrared termogun yang dilakukan setiap 4 jam operasi dengan menembakan langsung sinar inframerah pada komponen mesin tersebut. Pengukuran data lainnya seperti putaran mesin, tegangan, dan arus juga dilakukan setiap 4 jam operasi.

\subsection{Karakteristik Bahan Bakar B100 dan B20}

Bahan bakar yang digunakan dalam penelitian ini adalah bahan bakar B100 dan B20. B100 merupakan bahan bakar biodiesel murni dari Crude Palm Oil (CPO) yang merupakan produk dari PT. Pelita Agung Industri, sedangkan B20 merupakan campuran bahan bakar yang terdiri dari 20\% biodiesel minyak sawit dan 80\% bahan bakar diesel fosil, yang merupakan produk dari PT. Pertamina, Sifat fisik dan kimia bahan bakar B100 dan B20 disajikan pada Tabel 1. 
W. Saputro et al. / Journal of Mechanical Design and Testing 2(2), (2020), 125-136

Tabel 1. Standar spesifikasi bahan bakar

\begin{tabular}{|c|c|c|c|c|c|}
\hline No & Parameter Uji & Metode Uji & Satuan & $\begin{array}{c}\text { Hasil } \\
\text { Uji } \\
\text { B100 }\end{array}$ & $\begin{array}{c}\text { Hasil } \\
\text { Uji B20 }\end{array}$ \\
\hline 1 & Massa jenis pada $40{ }^{\circ} \mathrm{C}$ & ASTM D 1298-12b & $\mathrm{kg} \mathrm{m}^{-3}$ & 862,4 & - \\
\hline 2 & Massa jenis pada $15^{\circ} \mathrm{C}$ & - & $\mathrm{kg} \mathrm{m}^{-3}$ & - & 845,7 \\
\hline 3 & Viskositas kinematik pada $40^{\circ} \mathrm{C}$ & ASTM D 445-06 & $\mathrm{mm}^{2} / \mathrm{s}$ & 4,53 & 2,92 \\
\hline 4 & Angka setana & ASTM D6980-12 & & 61,0 & 56,7 \\
\hline 5 & Titik nyala & ASTM D 93-02 & ${ }^{\circ} \mathrm{C}$ & 177 & 65 \\
\hline \multirow{3}{*}{6} & Residu karbon & \multirow{3}{*}{ ASTM D 4530-07 } & \multirow{3}{*}{$\%\left(\mathrm{~mm}^{-1}\right)$} & - & nihil \\
\hline & (dalam contoh asli) & & & 0,040 & - \\
\hline & (dalam 10\% ampas distilasi) & & & 0,160 & - \\
\hline 7 & Suhu distilasi $90 \%$ & ASTM D 1160-06 & ${ }^{\circ} \mathrm{C}$ & 350 & 344 \\
\hline \multirow{3}{*}{8} & Kestabilan oksidasi & \multirow{3}{*}{ EN 15751-2009 } & \multirow{3}{*}{ Menit } & \multirow{3}{*}{1200} & - \\
\hline & Periode induksi & & & & \multirow{2}{*}{$>2880$} \\
\hline & Metode Rancimat & & & & \\
\hline 9 & Warna & ASTM D 1500 & Colour ASTM & 1,0 & 1,1 \\
\hline 10 & Kadar Ester metil & Calculation & $\%\left(\mathrm{~mm}^{-1}\right)$ & 98,24 & - \\
\hline 11 & Kandungan FAME & - & $\% \mathrm{v} / \mathrm{v}$ & - & 20 \\
\hline 12 & Kadar air & ASTM D 6304 & ppm & 267 & 159,63 \\
\hline
\end{tabular}

\section{HASIL DAN PEMBAHASAN}

\subsection{Daya dan Torsi}

Pengujian daya dan torsi mesin terhadap waktu operasi dituangkan dalam bentuk grafik seperti pada Gambar 2. Berdasarkan hasil analisis hingga 300 jam operasi diperoleh nilai daya rata-rata yang dihasilkan oleh mesin berbahan bakar B100 lebih rendah 2,17\% dibandingkan mesin berbahan bakar B20. Mesin berbahan bakar B100 memiliki nilai daya rata-rata sebesar 3,88 kW dan mesin berbahan bakar B20 memiliki nilai daya rata-rata sebesar 3,96 kW. Selanjutnya analisis torsi hingga 300 jam operasi diperoleh nilai rata-rata torsi yang dihasilkan oleh mesin berbahan bakar B100 lebih rendah 0,76\% dibandingkan mesin berbahan bakar B20. Mesin berbahan bakar B100 memiliki nilai torsi rata-rata sebesar 16,43 Nm dan mesin berbahan bakar B20 memiliki nilai torsi rata-rata sebesar 16,55 Nm. 


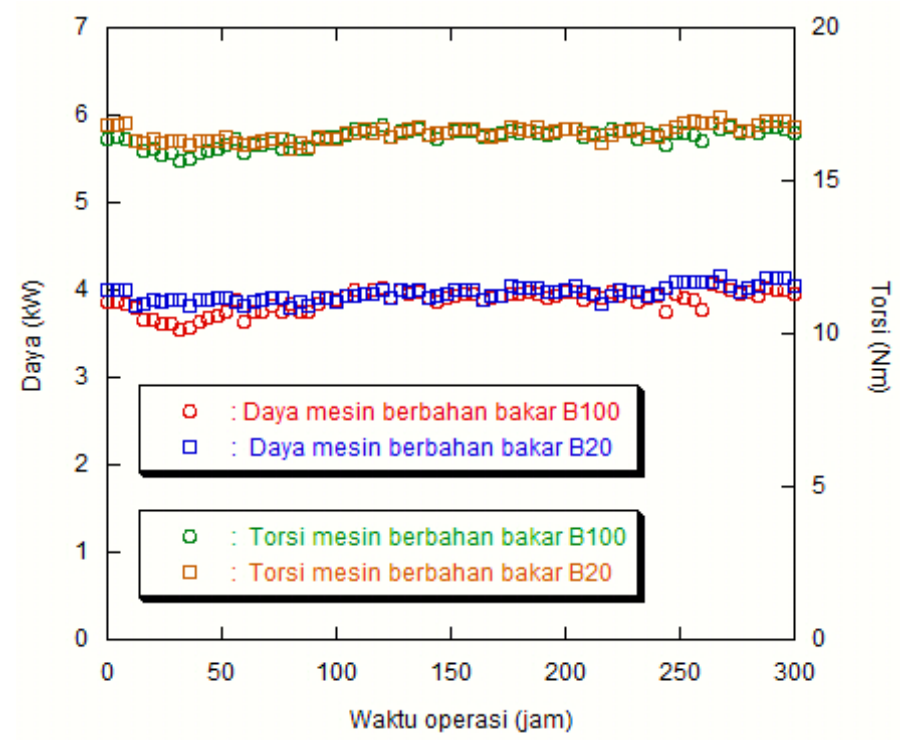

Gambar 2. Grafik daya dan torsi terhadap waktu operasi

Nilai daya dan torsi yang lebih rendah pada mesin berbahan bakar B100 dikarenakan bahan bakar B100 memiliki energy content yang lebih rendah, bahan bakar B100 memiliki energy content sebesar 39,9 MJ/kg sedangkan bahan bakar B20 memiliki energy content sebesar 43,8 $\mathrm{MJ} / \mathrm{kg}$. Nilai energy content tersebut didasarkan dari referensi yang memiliki kesamaan jenis tumbuhan sumber dari biodiesel tersebut, yaitu jenis Elaeis Guineensis (kelapa sawit), berasal dari PT. Phatum Company yang juga menyediakan B100 dan dari perusahaan lokal di Malaysia.

Bila dilihat dari hasil proses pembakaran B100 dalam bentuk emisi gas buang, dapat dikatakan pembakaran B100 ini terjadi dalam kondisi pembakaran sempurna, hal ini ditunjukkan dengan grafik pada Gambar 3, di mana emisi gas buang CO (karbon monoksida) dari pembakaran mesin berbahan bakar B100 lebih rendah bila dibandingkan dengan emisi akibat pembakaran B20. Hal tersebut dikarenakan bahan bakar B100 memiliki kandungan oksigen yang lebih tinggi dibandingkan bahan bakar B20, di mana kandungan oksigen bahan bakar B100 sebesar 11\% wt dan bahan bakar B20 sebesar 2,6\% wt. Kandungan oksigen yang lebih tinggi akan menjadikan pembakaran menjadi lebih sempurna. Pembakaran yang sempurna akan menghasilkan emisi gas buang yang lebih rendah, dimana $\mathrm{CO}$ akan dioksidasi menjadi $\mathrm{CO}_{2}$ (karbon dioksida). Secara teoritis, bahan bakar B100 memiliki karakteristik fisik viskositas dan densitas yang lebih tinggi dibandingkan dengan bahan bakar B20, berdasarkan Tabel 1 nilai densitas bahan bakar B100 adalah $862,4 \mathrm{~kg} / \mathrm{m}^{3}$ dan nilai viskositasnya adalah $4,53 \mathrm{~mm}^{2} / \mathrm{s}$, sedangkan nilai densitas bahan bakar B20 adalah $845,7 \mathrm{~kg} / \mathrm{m}^{3}$ dan nilai viskositasnya adalah 2,92 $\mathrm{mm}^{2} / \mathrm{s}$. Nilai viskositas dan densitas yang lebih tinggi ini akan membuat droplet dari proses atomisasi bahan bakar menjadi lebih besar bila dibandingkan dengan bahan bakar yang memiliki nilai viskositas dan densitas yang lebih rendah misalnya bahan bakar B20. Diameter droplet dari atomisasi yang besar akan menyebabkan surface contact (luas total permukaan kontak per satuan massa bahan bakar) antara bahan bakar dan udara menjadi lebih kecil sehingga permukaan yang tersedia untuk reaksi pembakaran menjadi lebih sedikit. Hal ini akan menyebabkan pembakaran antara bahan bakar dan udara di dalam ruang bakar menjadi kurang sempurna. Pada umumnya pembakaran yang kurang sempurna akan menghasilkan power dan torsi yang lebih rendah serta emisi gas buang CO yang lebih besar. Akan tetapi pada kasus pembakaran bahan bakar B100 
ini, efek dari tingginya viskositas dan densitas tidak mempengaruhi secara signifikan terhadap perubahan emisi gas buang bila dibandingkan dengan efek akibat tingginya kandungan oksigen dalam bahan bakar B100.

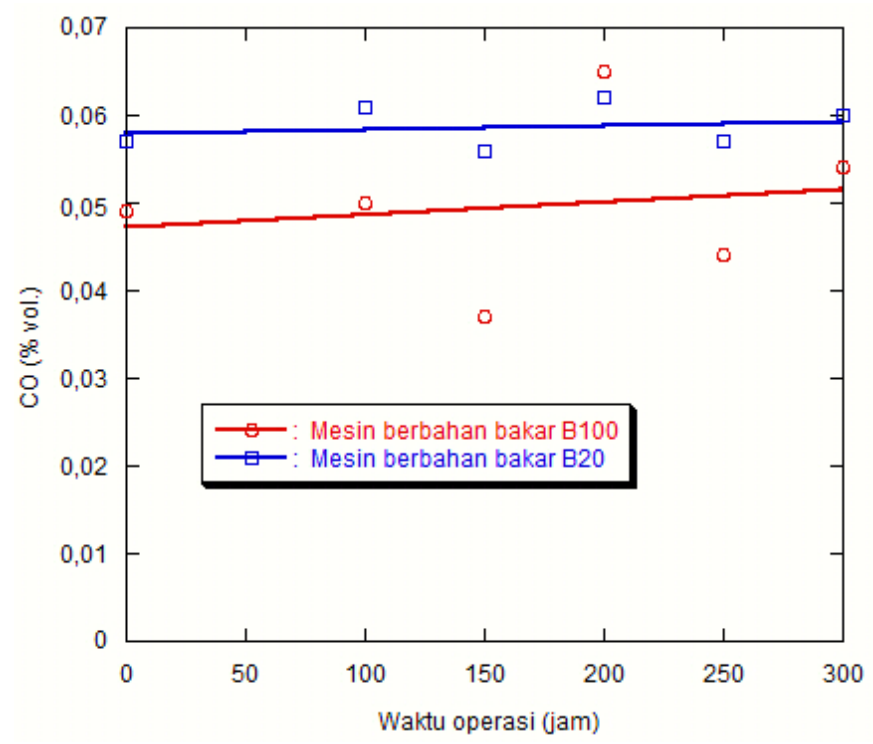

Gambar 3. Grafik emisi karbon monoksida terhadap waktu operasi

Hasil pengujian ini sesuai dengan hasil pengujian yang telah dilakukan Mofijur et al., mereka melakukan penelitian terkait daya yang dihasilkan oleh campuran bahan bakar B5 dan B10 dari kelapa sawit dengan bahan bakar solar sebagai pembandingnya. Berdasarkan hasil penelitiannya, daya yang dihasilkan oleh mesin berbahan bakar B0 lebih tinggi sebesar 1,38\% dibandingkan mesin berbahan bakar B5 dan lebih tinggi sebesar 3,16\% dibandingkan mesin berbahan bakar B10 dan daya yang dihasilkan mesin berbahan bakar B5 lebih tinggi dibandingkan mesin berbahan bakar B10. Selain itu, penelitian yang telah dilakukan oleh Ozsezen et al., yaitu terkait efek penggunaan bahan bakar biodiesel terhadap torsi yang dihasilkan, biodiesel yang digunakan adalah minyak goreng bekas dan bahan bakar solar sebagai pembandingnya. Berdasarkan hasil penelitiannya, torsi yang dihasilkan oleh mesin berbahan bakar minyak goreng bekas lebih rendah dibandingkan mesin berbahan bakar solar. 
W. Saputro et al. / Journal of Mechanical Design and Testing 2(2), (2020), 125-136

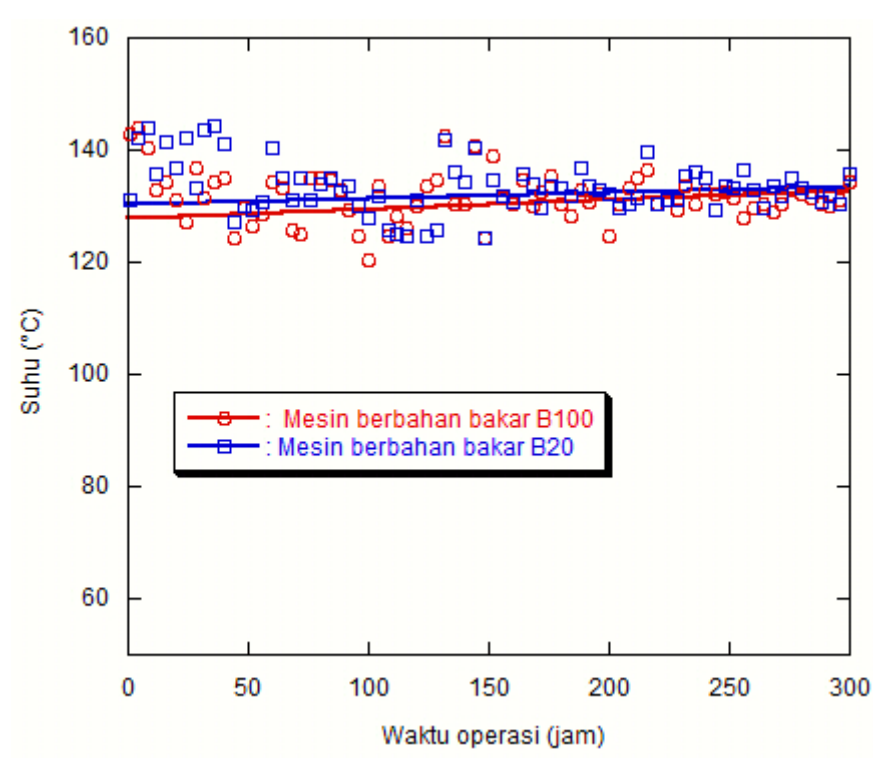

Gambar 4. Grafik suhu cylinder block terhadap waktu operasi

Berdasarkan Gambar 2 dapat dilihat bahwa daya dan torsi mesin berbahan bakar B100 dan B20 cenderung mengalami sedikit peningkatan seiring bertambahnya waktu operasi. Hal tersebut dikarenakan suhu pembakaran pada cylinder block (Gambar 4) yang mengalami peningkatan seiring berjalannya waktu operasi dan menyebabkan daya yang dihasilkan lebih tinggi. Suhu rata-rata cylinder block mesin berbahan bakar B20 adalah $132,04{ }^{\circ} \mathrm{C}$ dan pada mesin berbahan bakar B100 adalah $130,4^{\circ} \mathrm{C}$. Tetapi setelah waktu operasi tertentu, daya dan torsi relatif konstan dan terdapat penurunan yang dihasilkan akibat pembentukan deposit pada komponen mesin, keausan, serta menurunnya kualitas pelumas yang digunakan. Pada waktu operasi jam ke 16 hingga 52 dan waktu operasi jam ke 260, diketahui daya dan torsi mesin berbahan bakar B100 mengalami penurunan. Hal itu terjadi dikarenakan gangguan pada belt mesin berbahan bakar B100 sehingga menurunkan transmisi torsi.

\subsection{Specific Fuel Consumption (SFC) dan Efisiensi Termal}

Perhitungan specific fuel consumption (SFC) dan efisiensi termal terhadap waktu operasi dituangkan dalam bentuk grafik seperti pada Gambar 5. Specific fuel consumption adalah rasio antara laju aliran massa bahan bakar dan tenaga mesin. Pengukuran SFC diperoleh dengan mengukur waktu yang dibutuhkan oleh masing-masing mesin untuk menghabiskan $20 \mathrm{ml}$ baik bahan bakar B100 dan B20 di dalam buret. Perhitungan SFC didasarkan pada densitas bahan bakar yaitu $862,4 \mathrm{~kg} / \mathrm{m}^{3}$ untuk bahan bakar B100 dan 845,7 kg/m³ untuk bahan bakar B20 sesuai Tabel 1. Berdasarkan hasil analisis hingga 300 jam operasi diperoleh nilai SFC rata-rata yang dihasilkan oleh mesin berbahan bakar B100 lebih tinggi 14,6\% dibandingkan mesin berbahan bakar B20. Mesin berbahan bakar B100 memiliki nilai SFC rata-rata sebesar 0,317 kg/(kW.jam) dan mesin berbahan bakar B20 memiliki nilai SFC rata-rata sebesar 0,276 kg/(kW.jam).

Selanjutnya efisiensi termal didefinisikan sebagai hasil dari sebuah heat engine sebagai fungsi input termal melalui injeksi bahan bakar. Perhitungan efisiensi termal didasarkan pada asumsi nilai kalor kedua bahan bakar. Bahan bakar B100 memiliki energy content sebesar 39,9 $\mathrm{MJ} / \mathrm{kg}$ dan bahan bakar B20 memiliki energy content sebesar 43,8 MJ/kg. Berdasarkan hasil analisis 
hingga 300 jam operasi diperoleh nilai efisiensi termal rata-rata yang dihasilkan oleh mesin berbahan bakar B100 lebih rendah 1,25\% dibandingkan mesin berbahan bakar B20. Mesin berbahan bakar B100 memiliki nilai efisiensi termal rata-rata sebesar 28,49\% dan mesin berbahan bakar B20 memiliki nilai efisiensi termal rata-rata sebesar 31,05\%.

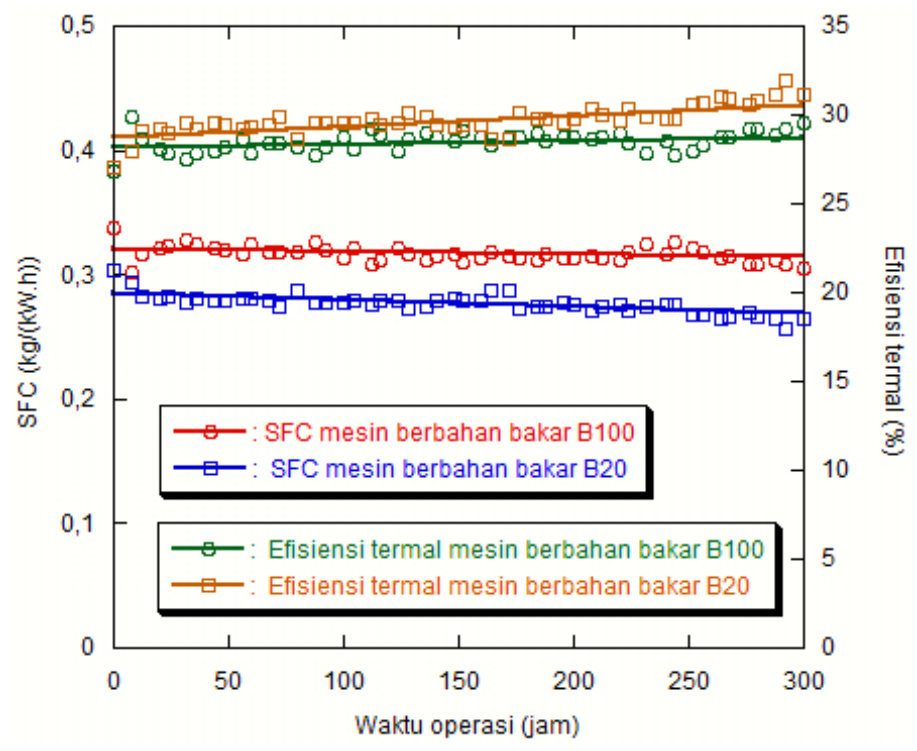

Gambar 5. Grafik specific fuel consumption dan efisiensi termal terhadap waktu operasi

Nilai rata-rata SFC yang lebih tinggi pada mesin berbahan bakar B100 dikarenakan bahan bakar B100 memiliki karakteristik energy content yang lebih rendah, memiliki kandungan oksigen yang lebih tinggi, dan nilai densitas yang lebih tinggi dibandingkan bahan bakar B20. Dengan demikian energy content yang lebih rendah dan densitas bahan bakar yang lebih tinggi membutuhkan aliran massa bahan bakar yang lebih besar untuk mencapai output energi yang sama dari mesin, yang mengarah ke peningkatan SFC untuk mengimbangi energi kimia yang berkurang dalam bahan bakar. Peningkatan SFC dipengaruhi oleh kadar campuran biodiesel yang terkandung dalam suatu bahan bakar, semakin tinggi persentasi campuran biodiesel menyebabkan lebih banyak aliran massa bahan bakar yang dikonsumsi untuk perpindahan yang sama dari plunger di pompa injeksi bahan bakar, sehingga meningkatkan SFC.

Berdasarkan Gambar 5 dapat dilihat bahwa SFC mesin berbahan bakar B100 dan B20 cenderung mengalami penurunan seiring bertambahnya waktu operasi. Hal tersebut dikarenakan faktor suhu pembakaran pada cylinder block kedua mesin yang semakin meningkat, peningkatan tersebut dibuktikan melalui grafik suhu gylinder block pada Gambar 4. Suhu di ruang bakar yang tinggi akan menghasilkan pembakaran yang lebih baik, kemudian tekanan menjadi semakin meningkat dan mengakibatkan performa mesin seperti daya, torsi, dan efisiensi termal yang semakin tinggi. Pengurangan konsumsi bahan bakar juga dapat diakibatkan oleh faktor-faktor seperti: (1) fenomena microexplosion (2) peningkatan udara yang masuk dikarenakan meningkatnya momentum semprotan (3) pembakaran premix karena ignition delay (4) meningkatnya campuran rasio udara karena kandungan oksigen di dalam bahan bakar dan (5) menghasilkan lebih banyak gas yang merupakan hasil produk pembakaran karena adanya air dan emulsi . 
Rendahnya nilai efisiensi termal pada mesin berbahan bakar B100 dikarenakan nilai specific fuel consumption yang lebih tinggi akibat energy content yang lebih rendah pada bahan bakar B100. Energy content yang lebih rendah mengakibatkan mesin berbahan bakar B100 membutuhkan konsumsi bahan bakar yang lebih tinggi dalam menghasilkan kerja yang sama. Peningkatan konsumsi bahan bakar dan penurunan daya mesin mengakibatkan efisiensi termal menjadi menurun. Panas atau tenaga yang dihasilkan oleh bahan bakar dapat diprediksi melalui besarnya konsumsi bahan bakar, sedangkan kerja mekanis dapat ditetapkan dari pengukuran daya mesin. Oleh karena itu, nilai efisiensi termal dipengaruhi oleh nilai konsumsi bahan bakar spesifik. Nilai efisiensi termal yang lebih rendah pada mesin berbahan bakar B100 menunjukkan proses konversi energi kimia menjadi energi mekanis pada bahan bakar B100 sedikit lebih buruk dibandingkan bahan bakar B20. Hasil pengujian ini sesuai dengan hasil pengujian yang telah dilakukan oleh Suthisripok and Semsamran, dimana mereka melakukan penelitian tentang efisiensi termal yang dihasilkan dari penggunaan bahan bakar B100 bersumber dari minyak kelapa sawit dan bahan bakar solar sebagai pembandingnya. Berdasarkan hasil penelitiannya, efisiensi termal yang dihasilkan oleh mesin berbahan bakar B100 lebih rendah dibandingkan mesin berbahan bakar solar. Mesin berbahan bakar B100 menghasilkan efisiensi termal sebesar 15,1\% dan mesin berbahan bakar solar menghasilkan efisiensi termal sebesar 15,3\%. Nilai efisiensi termal yang lebih tinggi pada penelitian ini bila dibandingkan dengan penelitian Suthisripok and Semsamran dikarenakan putaran mesin pada penelitian ini lebih tinggi yaitu sebesar $2200 \mathrm{rpm}$ sedangkan pada penelitian Suthisripok and Semsamran sebesar $1000 \mathrm{rpm}$. Saat putaran mesin meningkat kualitas pembakaran menjadi lebih baik, hal tersebut dikarenakan penguapan bahan bakar meningkat akibat suhu pembakaran di ruang bakar yang lebih tinggi. Hal tersebut sesuai dengan penelitian Nagaraja et al., yang menyatakan bahwa saat rpm mesin meningkat, efisiensi termal mesin juga akan meningkat dikarenakan terjadinya peningkatan kualitas pembakaran. Berdasarkan Gambar 5 dapat dilihat bahwa efisiensi termal mesin berbahan bakar B100 dan B20 cenderung mengalami peningkatan seiring bertambahnya waktu operasi. Hal tersebut dikarenakan fungsi efisiensi termal berbanding lurus dengan daya dan berbanding terbalik terhadap jumlah bahan bakar yang diinjeksikan ke dalam ruang pembakaran. Sehingga apabila daya meningkat, serta jumlah bahan bakar yang diinjeksikan semakin berkurang, maka efisiensi termal pada mesin akan meningkat dan begitu juga sebaliknya.

\subsection{Price to Power}

Hingga saat ini harga jual bahan bakar B100 belum ditentukan secara nasional dikarenakan bahan bakar B100 belum dijual secara komersial, walaupun demikian kita dapat membeli bahan bakar B100 namun dalam jumlah yang besar. Oleh sebab itu, analisis price to power dilakukan untuk menentukan harga jual bahan bakar B100 yang direkomendasikan bagi para konsumen. Perhitungan dilakukan, dengan asumsi bahwa harga kW/jam bahan bakar B100 sama dengan harga bahan bakar acuan, misalnya B20.

Penentuan harga jual yang direkomendasi untuk bahan bakar B100 yang dibandingkan bahan bakar B20 (dexlite) dilakukan dengan menggunakan data specific fuel consumption (SFC) kedua jenis bahan bakar. Nilai SFC rata-rata bahan bakar B100 dan B20 setelah 300 jam waktu operasi adalah 0,32 kg/(kW.jam) dan 0,28 kg/(kW.jam) secara berururtan. Serta densitas untuk bahan bakar B100 dan B20 adalah 0,86 kg/1 dan 0,85 kg/1 seperti ditunjukkan pada Tabel 1. Harga jual bahan bakar B20 (dexlite) non subsidi oleh PT. Pertamina (Persero) per Desember 2019 adalah Rp10.200/1. Berdasarkan informasi tersebut, kemudian dihitung harga bahan bakar B20 untuk tiap $\mathrm{kW}$.jam menggunakan persamaan 1. Di mana $A_{1}$ : harga bahan bakar acuan 
(Rp/l), B: SFC bahan bakar acuan (kg/(kW.jam)), @1: densitas bahan bakar acuan (kg/l), B: $\mathrm{SFC}$ bahan bakar rekomendasi $(\mathrm{kg} /(\mathrm{kW} . j \mathrm{am}))$, dan $\varrho_{2}$ : densitas bahan bakar rekomendasi (kg/l).

$$
\text { Harga rekomendasi }=\frac{\mathrm{A}_{1} \times \mathrm{B}_{1} \times \rho_{2}}{\mathrm{~B}_{2} \times \rho_{1}}=\frac{10.200 \times 0,276 \times 0,8624}{0,317 \times 0,8547}=\mathrm{Rp} 8.961 / \mathrm{l}
$$

Berdasarkan hasil perhitungan di atas, didapatkan harga jual maksimal yang direkomendasikan untuk bahan bakar B100 adalah Rp8.961/1, harga jual tersebut lebih rendah $12,15 \%$ dibandingkan harga jual bahan bakar B20, hal ini dikarenakan SFC pada bahan bakar B100 lebih tinggi sebesar 14,61\% dengan catatan harga diatas belum mempertimbangkan biaya yang belum dikeluarkan akibat perawatan. Bila dilakukan perbandingan perhitungan biaya dengan solar industri yang diasumsikan 100\% solar, maka perlu dilakukan beberapa asumsi yaitu SFC bahan bakar B100 lebih tinggi 17\% dibandingkan dengan SFC solar industri, dengan asumsi memiliki densitas sebesar $844 \mathrm{~kg} / \mathrm{m}^{3}$ dan harga jualnya sebesar Rp13.500/1. Berdasarkan datadata tersebut, dengan menggunakan Persamaan 1 didapatkan harga rekomendasi bahan bakar B100 untuk menggantikan solar industri adalah Rp11.500/1. Harga rekomendasi yang didapat lebih rendah 15,2\% dibandingkan dengan solar industri.

\section{KESIMPULAN}

Berdasarkan hasil penelitian yang telah dilakukan, dapat ditarik kesimpulan bahwa penggunaan bahan bakar B100 secara umum akan menghasilkan daya, torsi, dan efisiensi termal yang lebih rendah walaupun tidak signifikan, yaitu masing-masing sebesar 2,17\%; 0,76\%; dan 1,25\%. Akan tetapi bila membandingkan nilai SFC-nya, bahan bakar B100 menghasilkan SFC yang lebih tinggi sebesar 14,6\% bila dibandingkan mesin berbahan bakar B20. Hal tersebut dikarenakan karakteristik bahan bakar B100 yang memiliki energy content yang lebih rendah, memiliki nilai viskositas, dan densitas yang lebih tinggi dibandingkan bahan bakar B20. Nilai viskositas dan densitas yang lebih tinggi pada bahan bakar B100 memengaruhi rasio atomisasi yang terbentuk, sehingga mengurangi laju pencampuran bahan bakar dan udara. Nilai viskositas yang lebih tinggi membuat kondisi atomisasi bahan bakar menjadi buruk dan ukuran droplet yang lebih besar yaitu berupa evaporasi yang lebih miskin serta berpengaruh pada proses pencampuran udara dan bahan bakar saat proses pembakaran berlangsung, sehingga menghasilkan pembakaran yang tidak sempurna. Berdasarkan hasil analisis price to power harga jual maksimal yang direkomendasikan untuk bahan bakar B100 adalah Rp8.961/liter, di mana harga jual tersebut lebih rendah 12,15\% dibandingkan harga jual bahan bakar B20, dengan catatan harga diatas belum mempertimbangkan biaya yang dikeluarkan akibat perawatan.

\section{ACKNOWLEDGEMENT}

Penulis berterima kasih atas dampingan staf dan fasilitas yang telah diberikan diantaranya:

- Pembiayan oleh RTA (Rekognisi Tugas Akhir) dan ICA UGM

- Laboratorium Konversi Energi, Departemen Teknik Mesin dan Industri, Universitas Gadjah Mada 


\section{DAFTAR PUSTAKA}

BPH Migas, "Kuota dan Realisasi Jenis BBM Tertentu Tahun 2017", Available from: http://www.bphmigas.go.id/kuota-dan-realisasi-jenis-bbmtertentu\#tahun2017

Aji, S., Kusmaningrum., and Herni M, F., "Optimisasi Keuntungan Menggunakan Linear Programming di PT Pertamina Refinery Unit (RU) VI Balongan”, Jurnal Online Institut Teknologi Nasional, Vol.1, No.3., 2014.

Kuncahyo, P., M. Fathallah, A.Z., and Semin, "Analisa Prediksi Potensi Bahan Baku Biodiesel Sebagai Suplemen Bahan Bakar Motor Diesel di Indonesia", Jurnal Teknik POMITS, Vol.2, No.1, pp. 62-66, 2013.

Suthisripok and Semsamran, "The Impact of Biodiesel B100 on a Small Agricultural Diesel Engine”, Tribology International, Vol 128: 397-409, 2018.

Alloune, R., Balistrou, M., Awad, S., Loubar, K., and Tazerout, M., "Performance, Combustion and Exhaust Emissions Characteristics Investigation Using Citrullus colocynthis L. Biodiesel in DI Diesel Engine", Journal of the Energy Institute, Vol. 91, pp. 434-444, 2018.

Ozsezen et al., "Variable Valve Timing and Its Impacts on Air Parameters of an SI Engine", Journal of the Faculty of Engineering and Architecture, Gazi University, 2009.

Borhanipour, M., Karin, P., Tongroon, M., Chollacoop, N., and Hanamura, K., "Comparison Study on Fuel Properties of Biodiesel from Jatropha, Palm and Petroleum Based Diesel Fuel”, SAE Technical Paper, 2014.

Liaquat, A. M., Masjuki, H.H., Kalam, M.A., Fazal, M.A., Khan, F.A., Fayaz, H., and Varman, M., "Impact of Palm Biodiesel Blend on Injector Deposit Formation", Applied Energy, Vol.111, pp. 882-893, 2013.

Kegl, B., Kegl, M., and Pehan, S., "Green Diesel Engines Biodiesel Usage in Diesel Engines", Springer, London.

Mofijur, M., Masjuki, H.H., Kalam, M.A., Atabani, A.E., Rizwanul Fattah, I.M., and Mobarak, H.M., "Comparative Evaluation of Performance and Emission Characteristics of Moringa oleifera and Palm Oil Based Biodiesel in a Diesel Engine", Industrial Crops and Products, Vol. 53, pp. 78-84, 2014.

Rakopoulos D, Rakopoulos C, Kakaras E, Giakoumis E. Effects of ethanol-diesel fuel blends on the performance and exhaust emissions of heavy duty DI diesel engine. Energy Convers Manage 2008; 49:3155-62.

Gulzar M., Masjuki H.H., Kalam M.A, Varman M., and Fattah R.I.M., Oil Filter Modification for Biodiesel-Fueled Engine: A Pathway to Lubricant Sustainability and Exhaust Emissions Reduction, Energy Conversion and Management 91 (2015) 168-175.

Tripathi RK. and Gupta S., 2018, Evaluation of Engine Performance and Effect on Material of Engine Hardware Due to Prolonged Use of Neat Jatropha Oil and Their Blends in Indirect Injection Diesel Engines, proceedings 5 (2018) 28392-28401

M. Abu-Zaid, An experimental study of the evaporation characteristics of emulsion liquid droplets, Heat Mass Transf. 40 (9) 737-741.

Nagaraja S, Soorya Prakash K, Sudhakaran R, Sathish Kumar M, Investigation on the emission quality, performance and combustion characteristics of the compression ignition engine fueled with environmental friendly corn oil methyl ester-diesel blends, Ecotoxicol Environ Saf 2016; 134:455-61. https://doi.org/10.1016/j. ecoenv.2016.01.023 